\title{
Wojna hybrydowa jako nowe zjawisko w sztuce wojennej XXI wieku
}

\section{$\mathrm{W}$} OJNA ORAZ KONFLIKT ZBROJNY TO POJĘCIA, KTÓRE NIEUSTANNIE SPOTYKAJĄ się z chaosem koncepcyjnym. Ich definicje są niewyraźne, nie dające jasno określić czym de facto owe zjawiska są (oraz czym nie są). Podobnie mają się sprawy jeśli chodzi o klasyfikację wojen i konfliktów zbrojnych.

Karl von Clausewitz w swoim dziele „O wojnie” stwierdził, że „wojna stanowi kontynuację stosunków politycznych przy zastosowaniu innych środków" (Cesarz, Stadtmüller, 2002, s. 15). Jeśli by przyjąć to stwierdzenie za podstawę rozważań o wojnie, to należałoby uznać, iż ludzkość nazbyt ochoczo sięgała po owe środki. W samym XX w. wojny pochłonęły ogromne ilości istnień ludzkich w czasie rewolucji (np. Rewolucja Październikowa 1917 r.), obu wojen światowych, wojen domowych (np. Hiszpania 1936-1939) czy teżwojen regionalnych (np. wojna koreańska 1950-1953) i wojen plemiennych (np. ludobójstwo w Rwandzie 1994). Wiek XX to także okres polityczno-ideologiczno - militarnej rywalizacji dwóch największych mocarstw światowych, tj. Stanów Zjednoczonych i Związku Socjalistycznych Republik Radzieckich, która zyskała miano zimnej wojny. Bez wątpienia można zatem uznać miniony wiek za wiek wojen, określany czasem również jako „stulecie mega śmierci” (Artymiak, 2003, s. 38). Z drugiej strony, podjęto wiele kroków zmierzających do eliminowania wojny jako ostatecznego środka w rozstrzyganiu sporów. Skala tych przedsięwzięć była nieporównywalnie większa od jakichkolwiek innych działań czy układów z przeszłości. W tym miejscu należy przywołać takie organizacje i układy międzynarodowe jak Liga Narodów, Organizacja Narodów Zjednoczonych, Rada Europy, Powszechna Deklaracja Praw Człowieka, Konwencja Wiedeńska, i wiele innych przedsięwzięć o charakterze strukturalno-prawnym.

W potocznym pojęciu wojna jest przeciwieństwem pokoju. Pokój jest stanem naturalnym, natomiast wojna jest rozumiana jako stan ekstraordynaryjny (Artymiak, 2003, s. 38 - 40). Rozważania nad ge- 
nezą, przyczynami wojen, ich istotą i charakterem, a także nad sposobami i metodami osiągnięcia pokoju towarzyszyły ludzkości od starożytności. W problematyce stosunków międzynarodowych zagadnienia takie jak wojna i pokój, z nieodłącznie towarzyszącą im problematyką szeroko rozumianego bezpieczeństwa zajmują ważne miejsce. Skonstruowanie wyczerpującej definicji nie jest jednak łatwe. W nauce o stosunkach międzynarodowych pojęcie konfliktu zbrojnego ma szerszy charakter, niźli pojęcie wojny. Najbogatszy aparat pojęciowo-definicyjny skonstruowany został na Wydziale Badań nad Pokojem i Konfliktami Uniwersytetu w Uppsali (Szwecja) na potrzeby Uppsala Conflict Data Project (UCDP). Warto zauważyć, iż właśnie na tym aparacie pojęciowym opierają się analizy ze znanego Sztokholmskiego Instytutu Badań nad Pokojem (Stockholm International Peace Research Institute - SIPRI) oraz opracowania zamieszczane w prestiżowych Rocznikach SIPRI. UCDP zawiera definicję konfliktu zbrojnego, który ujęty jest jako: „stwierdzona poważna sprzeczność, dotycząca władzy (panowania) i/lub terytorium, angażująca użycie sił zbrojnych dwóch stron, z których przynajmniej jedna reprezentuje rząd państwa, którego skutkiem jest co najmniej 25 osób zabitych w wyniku prowadzonych walk" (Wallensteen, Sollenberg, 2001, s. 630 - 640). Na tej podstawie należy jednoznacznie stwierdzić, że konflikt zbrojny jest procesem wieloskładnikowym i wieloetapowym (patrz: tabela 1).

Tabela 1. Model faz konfliktu

\begin{tabular}{|c|c|c|c|c|}
\hline \multicolumn{5}{|c|}{ Użycie przemocy } \\
\hline \multicolumn{5}{|c|}{ Konflikt } \\
\hline \multicolumn{5}{|c|}{ Spór/dyskusja } \\
\hline Faza 1 & Faza 2 & Faza 3 & Faza 4 & Faza 5 \\
\hline $\begin{array}{c}\text { Spór: } \\
\text { trony } \\
\text { wchodzą } \\
\text { okseśr } \\
\text { przedonego }\end{array}$ & $\begin{array}{c}\text { Konflikt: } \\
\text { Opcja mili- } \\
\text { tarna ulega } \\
\text { urawdo - po- }\end{array}$ & $\begin{array}{c}\text { Przemoc: } \\
\text { Walki } \\
\text { pomiędzy zor- } \\
\text { ganizowanymi } \\
\text { siłami }\end{array}$ & $\begin{array}{c}\text { Konflikt po fa- } \\
\text { zie zbrojnej: } \\
\text { Opcja walki } \\
\text { nadal istnieje }\end{array}$ & $\begin{array}{c}\text { Spór po fazie } \\
\text { zbrojnej: } \\
\text { sprzeczność } \\
\text { nadal trwa }\end{array}$ \\
\end{tabular}

Źródło: J. Reginia-Zacharski, Studia Geopolitica, Rok (1) 2010/2011.

Wojna jest zjawiskiem węższym od konfliktu zbrojnego. Składają się na nią działania wojenne, tj. stan wojny i operacje prowadzone w ramach walki konwencjonalnej lub partyzanckiej, o zasięgu lokal- 
nym, regionalnym bądź światowym. Natomiast stan wojny to sytuacja prawna, w myśl której uznaje się istnienie wojny. Jego ogłoszenie pociąga za sobą określone skutki prawne dla państw zaangażowanych jako strony wojny, ale także dla państw trzecich (neutralnych i sojuszniczych) oraz osób fizycznych i prawnych. Powoduje zerwanie stosunków dyplomatycznych i konsularnych, z możliwością zawieszenia umów międzynarodowych włącznie. Państwa trzecie, niezwiązane układami sojuszniczymi ze stronami wojny, zobowiązane są do zachowania neutralności. Sam fakt wypowiedzenia wojny nie jest równoznaczny z prowadzeniem działań wojennych. Wojna może być prowadzona bez formalnego wypowiedzenia wojny. Możliwa jest także sytuacja odwrotna - brak prowadzonych działań wojennych pomimo formalnego wypowiedzenia wojny np. tzw. Dziwna Wojna pomiędzy Wielką Brytanią i Francją a III Rzeszą w okresie od października 1939 r. do maja 1940 r. (Micek, 2005, s. 45 - 49). Wojna może także trwać nadal, pomimo faktycznego zakończenia działań wojennych ${ }^{1}$.

W politologii, stosunkach międzynarodowych czy historii ogólnej istnieje wiele klasyfikacji konfliktów zbrojnych. Przywoływane wcześniej badania SIPRI opierają się na następującym podziale:

1. Wojny antyreżimowe (zwane również politycznymi i ideologicznymi) - w których państwo występuje przeciwko siłom powstańczym walczącym o przejęcie władzy;

2. Konflikty etniczno-narodowe - w większości są to akty masowej przemocy zlokalizowane wewnątrz państw, w których reżimy występują przeciwko grupom zorganizowanym wokół narodowych i etnicznych kryteriów (choć dopuszcza się scenariusz wojny międzypaństwowej na tym samym tle);

3. Konflikty/wojny międzypaństwowe;

4. Wojny dekolonizacyjne i z obcą okupacją - posiadające charakter etniczny, gdzie lokalne wspólnoty występują przeciwko obcym (zagranicznym) reżimom;

5. Konflikty między-etniczne - w których cele stron definiowane są w oparciu o interes grupy (konflikty pomiędzy klanami, plemionami, organizacjami o szowinistycznym nastawieniu itp.);

6. Wojny gangów - toczone przez aktorów niepaństwowych, z dużym udziałem elementów kryminalnych. Celem działań jest za-

${ }^{1}$ Taka sytuacja ma miejsce np. pomiędzy Japonią i Rosją, które ze względu na spór o Archipelag Wysp Kurylskich do chwili obecnej nie zawarły traktatu pokojowego kończącego II wojnę światową pomiędzy tymi krajami (Malendowski, Mojsiewicz, 200o, S. 125). 
spokojenie prywatnych interesów (np. zabezpieczenie własnych zasobów posiadania);

7. Ludobójstwo - zorganizowane, najczęściej przez instytucje państwa, akty masowych mordów, czystek etnicznych (Scherrer, 2003, s. 31 - 32).

Powyższa klasyfikacja nie obejmuje jednak dość nowego zjawiska, jakim jest konflikt toczony na terenach wschodniej Ukrainy od kwietnia 2014 r., coraz częściej określanego jako „wojna hybrydowa”. Wojna tocząca się w obwodach Ługańskim i Donieckim na wschodnich rubieżach Ukrainy jest formą niekonwencjonalnego konfliktu, w którym jedna ze stron oficjalnie nie ogłosiła stanu wojny, jednakże doniesienia $\mathrm{z}$ frontu jednoznacznie wskazują na to, kto jest w niej agresorem. Wojna niekonwencjonalna jest formą osiągnięcia celów militarnych poprzez osłabienie zdolności bojowych wroga przy użyciu innych niż konwencjonalne środki. Wojna hybrydowa jest połączeniem ataku sił specjalnych, najemników oraz ataku informacyjnego, np. cyberataku. Może przejawiać się także w równoczesnej blokadzie ekonomicznej i wojnie propagandowej (Bachmann, Gunneriusson, 2014, s. 78 - 79).

Z jednej strony wojna hybrydowa może przybrać bardziej subtelną formę, jak np. działania publicystów (propaganda rozpowszechniana przez sieć sponsorowanych przez władze Rosji portali medialnych w krajach Europy Zachodniej „Sputnik”) lub bardziej ewidentne jak blokada ekonomiczna (embargo na ukraińskie produkty czekoladowe). Wojna hybrydowa może mieć charakter wywrotowych operacji wywiadowczych (inwigilacja lub wpływ na działania rządu), sabotażu, ataków hakerów na infrastrukturę informatyczną kraju lub działań zastępczych grup partyzanckich (Popescu, 2015, s. 1). Jednakże w wojnie hybrydowej głównym celem przeciwnika jest wywarcie wpływu na populację i decydentów politycznych poprzez nieoficjalne działania, celem uniknięcia oficjalnego zaklasyfikowania napaści (Pindjak, 2014). Wojnę hybrydową cechuje wielowymiarowość - niszczenie przeciwnika na wielu płaszczyznach - militarnej, ekonomicznej, politycznej, informacyjnej oraz tożsamościowej.

W nowoczesnym świecie obok bezpieczeństwa lądowego, powietrznego, wodnego i przestrzeni kosmicznej bezpieczeństwo przestrzeni wirtualnej odgrywa coraz większą rolę. W dobie superszybkich komputerów, chmur przechowujących dane, wielofunkcyjnych smartfonów, duża część zadań administracji państwowej przenoszona jest do przestrzeni wirtualnej. Naraża to państwa na nowe niebezpieczeństwa oraz ataki, które mogą poważnie zdestabilizować ich funk- 
cjonowanie. Według Departamentu Obrony USA/ Stanów Zjednoczonych cyberterroryzmem jest bezprawny atak lub groźba takiego ataku przeciwko komputerom, sieciom komputerowym lub informacjom przechowanym na nich mający na celu zastraszenie lub wymuszenie na społeczeństwie lub rządzie danego kraju spełnienia określonych celów politycznych (Weimann, 2004, s.2- 3). W ostatnich latach hakerzy zaczęli prowadzić wirtualne akcje dywersyjne nie tylko celem demonstracji swoich zdolności, ale także na zlecenie jednych państw przeciwko innym państwom. W 2007 r. estoński system bankowy padł ofiarą cyberataku w ramach zemsty za usunięcie pomnika radzieckiego żołnierza w jednym z estońskich miast. Zanim pierwsze czołgi wjechały do Gruzji w 2008 r., rosyjscy hakerzy zaatakowali strony gruzińskiej administracji. W przypadku obecnej wojny na Ukrainie rosyjscy hakerzy nie zwlekali z próbami destabilizacji Ukrainy. W systemach administracji rządowej w czerwcu 2014 r. znaleziono wirusa „Snake”, który prawdopodobnie posłużył do szpiegowania i zaburzania systemów informatycznych (Górecki, 2014). Rosyjski wirus szpiegowski zaatakował 84 strony administracji publicznej, w tym strony premiera Ukrainy, przemysłu obronnego i służby dyplomatycznej. Miesiąc wcześniej, w dniu majowych wyborów prezydenckich, Rosjanie przeprowadzili akcję cyber-sabotażu na strony Centralnej Komisji Wyborczej. Celem ataku, za którym stał „CyberBerkut” było usunięcie rezultatu wyborów i tym samym zdestabilizowanie sytuacji w kraju w dniu wyborów prezydenckich. Za kilka mniejszych ataków odpowiedzialny jest rosyjski cyber-gang „Quedagh” używający narzędzia do cyberprzestępstw zwanego Black Energy (Gilbert, 2014). Cyber-wojna może mieć także lżejszy wymiar, jak np. ta, którą opisał Infosec Institute. Według tego ośrodka badawczego, Rosjanie rekrutują i ćwiczą „nową armię trolli internetowych", którzy mają za zadanie zmienić postrzeganie inwazji na Ukrainę. Piszą oni chwalące Rosję zaś oczerniające Ukrainę i jej sojuszników blogi, komentarze, uczestniczą w dyskusjach na głównych stronach medialnych świata zachodniego, takich jak np. „Fox News”, „Huffington Post”, „The Blaze”, „Politico”.

Mając główne ogólnorosyjskie media pod kontrolą przekonanie obywateli Rosji co do słuszności inwazji na Ukrainę nie było trudnym zadaniem dla Kremla. Chcąc jednak legitymizować rosyjskie działania na Ukrainie wśród jak najszerszej międzynarodowej opinii publicznej, Moskwa sięgnęła po szeroko zakrojoną kampanię informacyjną, której wspólnym mianownikiem jest platforma medialna „Sputnik”. Serwis ten zarządzany przez rosyjską agencję Rossija Siegodnia (daw- 
niej Ria Novosti) działa już w 14 krajach, w tym od niedawna w Polsce (Kowalczyk, 2015, s. 1). Jak podaje strona projektu Sputnik, „ukazuje wielobiegunowy świat, w którym każde państwo ma swoje narodowe interesy, kulturę i tradycję". Narracja prezentowana przez platformę Sputnik opiera się na przedstawieniu Rosji jako wyzwoliciela i ostoi demokracji, ofiary zachodniego spisku mającego doprowadzić obywateli Rosji na skraj ubóstwa - przy jednoczesnym oczernianiu Unii Europejskiej, Ukrainy oraz Stanów Zjednoczonych. Konflikt na Ukrainie według tego medium jest wynikiem polsko-amerykańskiego spisku sił wywiadowczych, który wymknął się spod kontroli po zorganizowaniu zamachu stanu na administrację Wiktora Janukowycza. Same nagłówki artykułów prezentowanych przez wspomnianą platformę dają obraz rozmiaru propagandy oraz przeinaczeń w sposobie prezentowania bieżących wydarzeń w stosunkach międzynarodowych, szczególnie tych mających jakikolwiek związek z konfliktem rosyjsko-ukraińskim. Politycy europejscy przedstawiani są jako niekompetentni, skorumpowani technokraci, opisywane są ich słabości, wyrwane z kontekstu wypowiedzi. Organizacje międzynarodowe (Organizacja Narodów Zjednoczonych, Organizacja Bezpieczeństwa i Współpracy w Europie) prezentowane są w świetle przychylności wobec działań Rosji. Perspektywa ta wpisuje się w opinię zamordowanego w lutym 2015 r. rosyjskiego opozycjonisty Borysa Niemcowa, który przy opisywaniu masowej propagandy użył słów Goebbelsa „im większe kłamstwo, tym lepsze; i kłamstwo należy powtarzać wiele razy".

Analizując obecny konflikt rosyjsko-ukraiński należy stwierdzić, że Rosja, upokorzona skutkami sankcji ekonomicznych ze strony UE, „w ramach” wojny hybrydowej nie stosuje gospodarczych środków nacisku wobec Ukrainy - poza ograniczeniami dostaw gazu. Jednakże znamiona wojny gospodarczej nosiły sakcje Kremla wobec ukraińskiej gospodarki podejmowane celem zablokowania podpisania umowy stowarzyszeniowej między Ukrainą a UE przed szczytem Partnerstwa Wschodniego w Wilnie w listopadzie 2013 r. Rosyjska Federalna Służba Celna w sierpniu 2013 r. wprowadziła obowiązek przedstawienia świadectwa pochodzenia towaru, który miał być przedstawiany przy wjeździe towaru z Ukrainy do Rosji. Przepis ten mocno uderzył w ukraiński eksport oraz doprowadził do znacznego wydłużenia czasu odprawy na granicy obu krajów, odbijając się na przychodach ukraińskich firm. W tym samym miesiącu rosyjska służba sanitarno-epidemiologiczna zakazała importu słodyczy produkcji ukraińskiego koncernu Roshen. Według Kosta Bondarenko, szefa kijowskiego Instytutu 
Ukraińskiej Polityki, celem tych sankcji ze strony Rosji było pokazanie Ukrainie, co może ją czekać w przypadku stowarzyszenia z UE. Retorsje te ze strony Moskwy i tak były łagodne w porównaniu z aktualnym stanem prawie otwartego konfliktu zbrojnego. Obserwując obecną „dziwną wojnę” na Ukrainie można wysnuć wniosek, że sankcje ekonomiczne służyły zastraszeniu Ukrainy przed jakąkolwiek próbą zbliżenia się do UE, zaś obecna wojna, poza wymiarem militarnym, ma wymiar propagandowo-informacyjny, jednakże nie stricte handlowy.

Na przykładzie działań zbrojnych na Ukrainie można stwierdzić, że aktywność tzw. „zielonych ludzików”2 wpisuje się w kryteria wojny hybrydowej. Ekspert wileńskiego Instytutu Stosunków Międzynarodowych Margarita Seselgyte udowadnia, iż (najemni) żołnierze rosyjscy stosują regularne i nieregularne sposoby prowadzenia wojny, część $\mathrm{z}$ nich powiązana jest z grupami kryminalnymi, ich umundurowanie nie jest jednolite ani oznaczone oraz działają w sytuacji, w której wojna nie została oficjalnie wypowiedziana (Seselgyte, 2014). Z kolei według analityków portalu IHS, obecnie na terytorium Ukrainy znajduje się 14400 żołnierzy rosyjskich, wspierających 29300 nielegalnie zorganizowanych formacji separatystycznych na wschodniej Ukrainie. Ponadto 29400 rosyjskich żołnierzy stacjonuje na Krymie oraz kolejne 55800 rozmieszczonych wzdłuż granicy rosyjsko-ukraińskiej. Według oficjalnej linii Kremla żadne jednostki rosyjskie nie zostały wysłane na Ukrainę, poza wolontariuszami (Johnson, 2015).

Problem wojny hybrydowej precyzyjnie wyjaśnił generał Stanisław Koziej w wywiadzie dla Radia Zet. Szef Biura Bezpieczeństwa Narodowego zaznaczył, iż „może to być konflikt, w którym [...] wojska będą ukrywać się za anonimowymi ludźmi, prowadzącymi działania terrorystyczne, operacje, które trudno zakwalifikować”. Wojnę te dobrze określa także słowo „dwuznaczność”, w której śmiało możemy sobie zadać pytanie: czy „zielone ludziki” to uzbrojeni cywile, czy to już żołnierze? (Wójcik, 2014). Armia ta nazywana jest „armią duchów” i stanowi wielką siłę wsparcia działań separatystów na zmieniającym się froncie. Jednakże oficjalna linia Rosji nie znajduje potwierdzenia w informacjach z agencji prasowych, od rodzin zaginionych rosyjskich żołnierzy, czy pracowników organizacji praw człowieka. Kolejnym dowo-

${ }^{2}$ Mianem „zielonych ludzików” określano w czasie konfliktu o Krym w 2014 r. oddziały militarne, biorące udział w konflikcie zbrojnym, pozostające bez formalnej przynależności do którejkolwiek ze stron tegoż konfliktu (m.in. brak oznaczeń i emblematów świadczących o przynależności państwowej), działające na rzecz i na rozkaz podmiotu de iure niezaangażowanego $\mathrm{w}$ działania zbrojne. 
dem tego są paszporty Rosjan zebrane na polu walki i pokazane przez prezydenta Poroszenko podczas Konferencji Bezpieczeństwa w Monachium, którzy rzekomo byli na wakacjach na Ukrainie lub na „wyjeździe służbowym".

Wojna hybrydowa w drugiej dekadzie XXI w. przedstawia się jako idealna alternatywa dla zaatakowania lub zdestabilizowania innego kraju przez państwo, które z różnych względów nie chce angażować się w otwarty konflikt zbrojny. Oficjalne ogłoszenie wojny wiąże się z o wiele poważniejszymi sankcjami międzynarodowymi oraz alienacją na arenie międzynarodowej niż wielowymiarowe podkopywanie stabilności atakowanego kraju. Dlatego też decydenci na Kremlu zdecydowali się na wspieranie prorosyjskich separatystów w Donbasie bez jawnego angażowania się militarnie oraz na metodyczne zaprzeczenia jakimkolwiek oskarżeniom o wysyłanie żołnierzy i artylerii do tego regionu. Działania podejmowane przez Rosję na terytorium Ukrainy zmierzają do podporządkowania sobie tego państwa oraz uniemożliwienia mu integracji $\mathrm{z}$ zachodnioeuropejskimi strukturami militarnymi i politycznymi, co oznaczałoby wypadnięcie Ukrainy z rosyjskiej strefy wpływów. Za Zbigniewem Brzezińskim można stwierdzić, że geografia jest czasem największym przekleństwem kraju. Ukraina, jak opisuje ów amerykański politolog, jest państwem piwotalnym i zawsze będzie stała na drodze Rosji do osiągnięcia imperialnej pozycji i dlatego też Rosja będzie dążyła do kontrolowania tego państwa w różnorodny sposób. Dzięki nowoczesnym technologiom, propagandzie, destabilizacji infrastruktury informatycznej oraz poprzez konwencjonalne ataki militarne, Rosja skutecznie niszczy i dezintegruje kraj nad Dnieprem. Wojna hybrydowa jest we współczesnych warunkach jednym z największych zagrożeń bezpieczeństwa międzynarodowego - o czym uświadamiają nam informacje napływające z Ukrainy. Świat zachodni przygląda się tej wojnie z bezpiecznej odległości, jednak jest to kwestia czasu, kiedy jej skutki mogą okazać się dotkliwe dla jego społeczeństw, gospodarki oraz bezpieczeństwa.

Współczesna wojna, jako zjawisko obejmujące wszelkie aspekty życia człowieka, powoduje, iż zbyt sztywne trzymanie się wąskich kwalifikacji badawczych jest mocno ryzykowne. W wojnach nowego typu, do jakich zaliczyć można z pewnością wojnę hybrydową, rozdzielenie cywilów i żołnierzy jest przedsięwzięciem niewykonalnym. Traktowanie społeczeństwa jako rezerwuaru możliwości prowadzenia wojny wydaje się normą. Nie jest to oczywiście zjawisko nowe, niemniej jednak z całą pewnością skala oraz głębokość problemu stanowią nową 
jakość. Wykorzystywanie wszelkich dziedzin aktywności społecznej i państwowej do prowadzenia konfliktu, stwarza potencjalne szerokie możliwości wywierania wpływu o charakterze siłowym bez formalnego używania sił zbrojnych. Analizowane powyżej aspekty dalekie są od wyczerpania tematu definiowania i charakteryzowania wojny hybrydowej. Stanowią jednak pewną podstawę, na bazie której możliwe jest formułowanie hipotez badawczych w pogłębionych badaniach nad omawianym zjawiskiem.

\section{BIBLIOGRAFIA}

Artymiak R. (2003), Wojny i konflikty XX wieku, Wydawnictwa AGH, Kraków.

Bachmann S. D., Gunneriusson H. (2014), Hybrid Wars: The 21st Century's New Threats to Global Peace and Security, „Scientia Militaria. South African Journal of Military Studies", Vol 43 No. 1.

Cesarz Z., Stadtmüller E. (2002), Problemy polityczne wspótczesnego świata, Wydawnictwo Uniwersytetu Wrocławskiego, Wrocław.

Gilbert D., Black Energy Cyber Attacks Against Ukrainian Government Linked to Russia, 26.09.2014, „International Bussines Times”, http://www. ibtimes.co.uk/blackenergy-cyber-attacks-against-ukrainian-governmentlinked-russia-1467401, 29.11.2015.

Górecki P., Cyberatak na Ukrainę. Trudno będzie udowodnić, że to Rosja, 13.03.2014, „Gazeta Wyborcza”, http://wyborcza.pl/1,76842,15614511,Cyberatak_na_Ukraine__Trudno_bedzie_udowodnic_ze.html, 10.11.2015.

Johnsson R. F., UPDATE: Russia's hybrid war in Ukraine, is working, 26.02.2015, http://www.janes.com/article/49469/update-russia-s-hybrid-war-in-ukraine-is-working, 12.12.2015.

Kowalczyk M., Sputnik ruszył z rosyjską propaganda po polsku, 23.02.2015, Press.pl, ruszyl-z-rosyjska-propaganda-po-polsku, 02.12.2015.

Malendowski W., Mojsiewicz Cz. (2000), Stosunki międzynarodowe, Agencja Wydawniczo-Reklamowa Atla 2, Wrocław.

Micek P. (2005), Dziwna wojna, Wydawnictwo Uniwersytetu w Białymsto$k u$, Białystok.

Pindjak P. (2014) Deterring hybrid warfare: a chance for NATO and the EU to work together?, 10.11.2014, http://www.nato.int/docu/review/2014/ Also-in-2014/Deterring-hybrid-warfare/EN/index.htm, 21.12.2015.

Popescu N. (2015), Hybrid war: Neither new nor Russian, 03.02.2015, http://blogs.euobserver.com/popescu/2015/02/03/hybrid-war-neither-new-nor-russian/, 20.12.2015. 
Reginia-Zacharski J. (2011), Analityczne definicje wojny, „Studia Geopolitica”, Rok (1) 2010/2011.

Scherrer Ch. P. (2003), Ethnicity, Nationalism and Violence. Conflict Management, Human Rights, and Multilateral Regimes, Ashgate, Aldershot.

Weimann G. (2004), Cyberterrorism,How Real is the Threat? 13.09.2004, http://www.usip.org/sites/default/files/sr119.pdf, 20.11.2015.

Wallensteen P., Sollenberg M. (2001), Armed Conflict 1989-200o, „Journal of Peace Research", nr 38(5), Londyn.

Wójcik Ł., Ukraińska wojna hybrydowa. Wojna typu zgaduj-zgadula, 13.05.2014, „Polityka”, http://www.polityka.pl/tygodnikpolityka/swiat/1579805,1,ukrainska-wojna-hybrydowa.read, 15.12.2015.

\section{SUMMARY}

This article provides an insight into a new type of war - a hybrid war, which manifest itself through actions of Russia on the area of Eastern Ukraine. The author makes an attempt to classify hybrid war among other armed conflicts defined in the study of international security and relations, simultaneously trying to determine characteristic features of this phenomenon. The author hypothesize that deeper research into the problem may result in the necessity of creating new evaluative framework other than the one used for the conventional conflicts.

\section{Nota o Autorze}

Przemysław Renn [przemyslaw.renn@gmail.com] - absolwent i doktorant Wydziału Nauk Politycznych i Dziennikarstwa Uniwersytetu im. Adama Mickiewicza w Poznaniu, także absolwent Wydziału Prawa, Prawa Kanonicznego i Administracji Katolickiego Uniwersytetu Lubelskiego Jana Pawła II. Jego zainteresowania koncentrują się na tematyce integracji europejskiej, kwestiach bezpieczeństwa międzynarodowego oraz handlu międzynarodowego. 